JRNAL ПMПAH

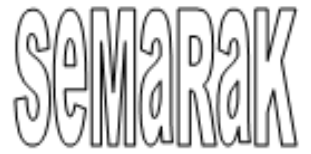

P-ISSN 2615-6849, E-ISSN 2622-3686

Jurnal Semarak,Vol.4,No.3,Oktober 2021, Hal (70-77)

@Prodi Manajemen Fakultas Ekonomi Universitas Pamulang

\title{
ANALISIS RASIO KECUKUPAN MODAL, KELANCARAN KREDIT DAN BIAYA OPERASIONAL PENGARUHNYA TERHADAP KEMAMPUAN MENGHASILKAN LABA PADA PT BANK OCBC NISP, Tbk.
}

\author{
Nani, Endang Puji Astutik, Fahrur Rozi \\ Dosen Program Studi Manajemen, Universitas Pamulang \\ dosen01704@unpam.ac.id, dosen01682@unpam.ac.id, \\ ozie.x.pancur@gmail.com
}

\begin{abstract}
ABSTRAK
Penelitian ini dilakukan untuk mengetahui pengaruh antara rasio kecukupan modal (Capital Adequacy Ratio),kelancaran kredit (Loan to Deposits Ratio) dan biaya operasional (BOPO) terhadap kemampuan menghasilkan laba pada PT.Bank OCBC NISP,Tbk. Jenis penelitian adalah kuantitatif. Data yang digunakan bersumber dari laporan keuangan melalui annual report PT. Bank OCBC NISP,Tbk periode tahun 2014-2019. Uji Statistik yang digunakan untuk mengolah data yaitu regresi berganda dan uji asumsi klasik. Dari penelitian ini dapat disimpulkan bahwa secara simultan antara rasio kecukupan modal,kelancaran kredit dan biaya operasional memiliki dampak yang positif dan signifikan pada kemampuan perusahaan untuk menghasilkan laba.
\end{abstract}

Kata Kunci: Capital Adequacy Ratio, Loan to Deposits Ratio, Biaya Operasional Pendapatan Operasional(BOPO), Return on assets

\begin{abstract}
This study was conducted to determine the effect of the capital adequacy ratio (Capital Adequacy Ratio), credit smoothness (Loan to Deposits Ratio) and operating costs (BOPO) on the ability to generate profits at PT.Bank OCBC NISP,Tbk. This type of research is quantitative. The data used are sourced from financial reports through the annual report of PT. Bank OCBC NISP, Tbk for the period 2014-2019. The statistical test used to process the data is multiple regression and classical assumption test. From this research, it can be concluded that simultaneously the ratio of capital adequacy, credit smoothness and operational costs has a positive and significant effect on the company's ability to get profits.
\end{abstract}

Keywords: Capital Adequacy Ratio, Loan to Deposits Ratio, Operating Costs, Operating Income (BOPO), Return on assets 
JRNAL ПMПAH Sammandald
P-ISSN 2615-6849, E-ISSN 2622-3686

Jurnal Semarak,Vol.4,No.3,Oktober 2021, Hal (70-)

@Prodi Manajemen Fakultas Ekonomi Universitas Pamulang
1. PENDAHULUAN

A. Latar Belakang

Saat ini sektor perbankan mendominasi Perekonomian Indonesia karena industri perbankan memegang peranan penting dalam pembangunan ekonomi sebagai financial intermediary atau perantara antara pihak-pihak keuangan. Mereka yang membutuhkan kelebihan dan uang serta mematuhi peraturan No.51/POJK.03/2017. Dijelaskan dalam hukum Negara Republik Indonesia. Ke-10 bank pada tahun 1998 terkait dengan bank, yaitu organisasi komersial yang menghimpun uang dari masyarakat dalam bentuk simpanan dan menyalurkannya kepada masyarakat dalam bentuk kredit dan bentuk lainnya untuk meningkatkan taraf hidup masyarakat umum. Ada banyak cara untuk menilai kondisi suatu bank sehat ataukah tidak yaitu melalui modal, ekuitas, manajemen, bunga, likuiditas. Aspek-aspek tersebut kemudian dinilai dengan menggunakan indikator keuangan untuk menilai posisi keuangan perusahaan perbankan tersebut (Muchtar dkk ,2016). Rasio Capital Adequacy Ratio (CAR) adalah rasio yang digunakan untuk mengukur kemampuan permodalan yang ada untuk menutup kemungkinan kerugian di dalam kegiatan perkreditan dan perdagangan surat-surat berharga (Widyatuti,2017). Capital Adequacy Ratio (CAR) periode tahun 2014-2019 di PT Bank OCBC NISP, Tbk masih terlihat fluktuatif walaupun memenuhi standar rasio penyediaan modal yang diwajibkan yaitu minimum $8 \%$ lebih lengkapnya periode dapat dilihat dari tabel di bawah ini.
Hasil perhitungan Rasio CAR

(dalam milyar rupiah) kecuali dinyatakan lain

\begin{tabular}{llll}
\hline Tahun & Modal & ATMR & CAR \\
\hline 2014 & 15361 & 81968 & $18,74 \%$ \\
\hline 2015 & 17488 & 100983 & $17,32 \%$ \\
\hline 2016 & 20305 & 111058 & $18,28 \%$ \\
\hline 2017 & 22440 & 128164 & $17,51 \%$ \\
\hline 2018 & 25043 & 142060 & $17,63 \%$ \\
\hline 2019 & 28297 & 147584 & $19,17 \%$ \\
\hline Sumber : Data diolah dari & Laporan \\
Keuangan PT Bank OCBC NISP, Tbk.
\end{tabular}

Rasio yang digunakan untuk mengukur komposisi jumlah kredit yang diberikan dan jumlah dana masyarakat dan aset yang digunakan atau disebut juga Loan to Deposit Ratio (LDR)(Kasmir,2018). Meski terjadi fluktuatif pada Loan to Deposits Ratio (LDR) pada PT Bank OCBC NISP, Tbk menunjukan semua LDR dari tahun 2014 sampai tahun 2019 telah memenuhi kriteria standar kewajiban jangka pendek yang $\leq 100 \%$ dari yang ditentukan oleh Bank Indonesia untuk detailnya dapat dilihat tabel dibawah ini.

Tabel 2

Hasil perhitungan Rasio LDR

(dalam milyar rupiah) kecuali dinyatakan

\begin{tabular}{llll}
\hline Tahun & $\begin{array}{l}\text { Laba } \\
\text { Sebelum } \\
\text { Pajak }\end{array}$ & $\begin{array}{l}\text { Total } \\
\text { Aset }\end{array}$ & ROA \\
\hline 2014 & 1776 & 103111 & $1,72 \%$ \\
\hline 2015 & 2001 & 120480 & $1,66 \%$ \\
\hline 2016 & 2351 & 138196 & $1,70 \%$ \\
\hline 2017 & 2877 & 153773 & $1,87 \%$ \\
\hline 2018 & 3485 & 173582 & $2,01 \%$ \\
\hline 2019 & 3891 & 180706 & $2,15 \%$ \\
\hline \multicolumn{4}{c}{ lain } \\
\end{tabular}

Sumber : Laporan Keuangan PT Bank OCBC NISP, Tbk.

Tabel 1 
JRNAL ПMПAH

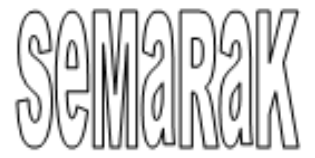

P-ISSN 2615-6849, E-ISSN 2622-3686

Jurnal Semarak,Vol.4,No.3,Oktober 2021, Hal (70-)

@Prodi Manajemen Fakultas Ekonomi Universitas Pamulang
Biaya operasional dan pendapatan operasional (BOPO) yaitu rasio yang digunakan untuk mengukur efisiensi dan kapasitas bank dalam menjalankan kegiatan operasionalnya. (Hartini,2016). Nilai BOPO sebesar 74,43, dan pada tahun 2019 sebesar $74,77 \%$. Berdasarkan tabel di atas dapatdilihat bahwa nilai biaya operasional pendapatan operasional masih dibawah standar yang ditentukan Bank Indonesia sebesar 90\%. Sehingga BOPO PT. Bank OCBC NISP, Tbk dalam tingkat efisiensi dalam operasionalnya masih dalam batas aman.

Tabel 3

Hasil perhitungan Rasio BOPO

(dalam milyar rupiah) kecuali dinyatakan lain

\begin{tabular}{llll}
\hline Tahun & $\begin{array}{l}\text { Beban } \\
\text { OP }\end{array}$ & $\begin{array}{l}\text { Pendapatan } \\
\text { OP }\end{array}$ & BOPO \\
\hline 2014 & 6874 & 8650 & $79,46 \%$ \\
\hline 2015 & 8075 & 10075 & $80,15 \%$ \\
\hline 2016 & 9279 & 11619 & $79,86 \%$ \\
\hline 2017 & 9672 & 12549 & $77,07 \%$ \\
\hline 2018 & 10145 & 13632 & $74,43 \%$ \\
\hline 2019 & 11520 & 15408 & $74,77 \%$ \\
\hline
\end{tabular}

Sumber: Laporan Keuangan PT Bank OCBC NISP, Tbk.

Return on assets (ROA) adalah kemampuan bisnis untuk menghasilkan keuntungan dari semua aset yang dimilikinya. (Diana,2018). Meski nilai Return On Assets PT Bank OCBC NISP, Tbk mengalami fluktuatif setiap tahunnya, tetapi dari penetapan peringkat rentabilitas yang dikeluarkan Bank Indonesia sebesar 1,25\%, ROA PT Bank OCBC NISP, Tbk dalam posisi sehat.Dalam melakukan penelitian ini peneliti mmemiliki maksud dan tujuan untuk dapat mengetahui besaran pengaruh rasio kecukupan modal, kelancaran kredit, dan biaya operasional terhadap kemampuan menghasilkan laba PT. Bank OCBC NISP Tbk. Disebabkan karena ketiga tersebut dapat mempengaruhi kemampuan menghasilkan laba PT. OCBC NISP Tbk.

Tabel 4

Hasil perhitungan Rasio ROA

\begin{tabular}{llll}
\hline Tahun & $\begin{array}{l}\text { Totak } \\
\text { Kredit }\end{array}$ & $\begin{array}{l}\text { Total } \\
\text { DPK }\end{array}$ & LDR \\
\hline 2014 & 68363 & 72805 & $93,90 \%$ \\
\hline 2015 & 85879 & 87280 & $98,39 \%$ \\
\hline 2016 & 93363 & 103599 & $90,12 \%$ \\
\hline 2017 & 106349 & 113440 & $93,75 \%$ \\
\hline 2018 & 117834 & 125560 & $93,85 \%$ \\
\hline 2019 & 119046 & 126121 & $94,39 \%$ \\
\hline \multicolumn{4}{c}{ dalam milyar rupiah) kecuali } \\
dinyatakan lainlain
\end{tabular}

Sumber : Laporan Keuangan PT Bank OCBC NISP, Tbk.

\section{B. Rumusan Masalah}

Berdasarkan latar belakang penelitian, maka peneliti dapat merumuskan beberapa masalah antara lain:

a) Apakah terdapat pengaruh antara rasio kecukupan modal terhadap kemampuan bank menghasilkan laba pada PT Bank OCBC NISP, Tbk. ?

b) Apakah terdapat pengaruh antara keadaan kredit terhadap kemampuan bank menghasilkan laba pada PT Bank OCBC NISP, Tbk. ?

c) Apakah terdapat pengaruh antara Biaya Operasional Pendapatan Operaisional terhadap kemampuan bank menghasilkan laba pada PT Bank OCBC NISP, Tbk. ?

d) Apakah terdapat pengaruh antara rasio kecukupan modal,keadaan kredit dan BOPO terhadap kemampuan bank menghasilkan laba pada PTBank OCBC NISP, Tbk.?

\section{Tujuan Penelitian}

a) Untuk mengetahui sejauhmana pengaruh antara rasio kecukupan modal terhadap kemampuan bank menghasilkan laba pada PT Bank OCBC NISP, Tbk. ? 
JRNAL ПMПAH

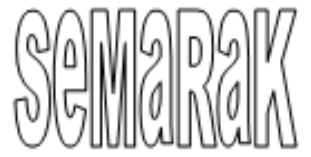

P-ISSN 2615-6849, E-ISSN 2622-3686

Jurnal Semarak,Vol.4,No.3,Oktober 2021, Hal (70-77)

@Prodi Manajemen Fakultas Ekonomi Universitas Pamulang b) Untuk mengetahui sejauhmana pengaruh antara keadaan kredit terhadap kemampuan bank menghasilkan laba pada PT Bank OCBC NISP, Tbk. ?

c) Untuk mengetahui sejauhmana pengaruh antara Biaya Operasional Pendapatan Operasional terhadap kemampuan bank menghasilkan laba pada PT Bank OCBC NISP, Tbk. ?

d) Untuk mengetahui sejauhmana pengaruh antara rasio kecukupan modal,keadaan kredit dan BOPO terhadap kemampuan bank menghasilkan laba pada PT Bank OCBC NISP, Tbk.?

\section{TINJAUAN PUSTAKA \\ Pengertian Rasio Keuangan}

Yaitu Rasio keuangan dirancang untuk membantu mengevaluasi laporan keuangan atau membantu kita mengidentifikasi beberapa kekuatan dan kelemahan keuangan perusahaan. Rasio keuangan juga sebagi alat pembanding posisierusahaan dengan pesaing, untuk kebijakan keuangan perusahaan kedepan. Rasio keuangan dapat dikelompokan ke dalam beberapa kelompok yaitu (Hidayat,2018)

\section{Capital Adequacy Ratio (CAR)}

Yaitu rasio yang digunakan untuk mengukur kemampuan permodalan yang ada untuk menutup kemungkinan kerugian di dalam kegiatan perkreditan dan perdagangan surat-surat berharha (Widyatuti,2017).

\section{Loan to Deposits Ratio (LDR}

Rasio yang digunakan untuk mengukur komposisi jumlah kredit yang diberikan terhadap jumlah dana masyarakat dan modal yang digunakan (Kasmir,2018).

\section{Biaya Operasional Pendapatan Operaisional (BOPO) \\ Merupakan rasio efisiensi yang digunakan untuk megukur kemampuan manajemen bak dalam mengendalikan biaya opersional}

terhadap pendapatan operasional (Pandia,2012).

\section{Return On Asset (ROA)}

Adalah kemampuan perusahaan dalam menghasilkan laba dengan asset yang dimiliki perusahaan (Diana,2018).

\section{METODE PENELITIAN}

Jenis penelitian yang digunakan dalam penelitian ini adalah penelitian kuantitatif. Metode penelitian kuantitatif merupakan salah satu jenis penelitian yang spesifikasinya adalah sistematis, terencana dan terstruktur dengan jelas sejak awal hingga pembuatan desain penelitiannya. Metode penelitian kuantitatif, sebagaimana dikemukakan oleh Sugiyono (2018:7) yaitu : "Metode yang berlandaskan pada filsafat positivisme, metode yang memenuhi kaidah-kaidah ilmiah yaitu konkrit, obyektif, terukur, rasional, dan sistematis. Serta data penelitian berupa angka-angka dan analisis menggunakan statistik".

objek penelitian yaitu pada PT Bank OCBC NISP,Tbk.sedangkan data sekunder diperoleh dari website www.ocbcnisp.com dan www.idx.co.id. pengumpulan data mempergunakan data skunder, yaitu sumber data PT. OCBC Teknik dalam NISP Tbk.yang sudah terdokumentasi dan publish di bursa efek indonesia. Riset yang akan dikerjakan memiliki tujuan yaitu mengetahui seberapa besar kontribusi variabel rasio kecukupan modal,kelancaran kredit dan biaya operasional terhadap kemampuan menghasilkan laba perusahaan baik secara parsial maupun secara simultan maka uji pra syarat datanya yaitu menggunakan Uji hipotesis klasik meliputi uji normatif, uji multikolinearitas, uji varians variabel, dan uji autokorelasi.

\section{HASIL DAN PEMBAHASAN}

Pengujian Normalitas 
JRNAL ПMПAH

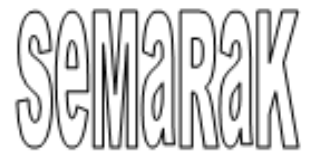

Pengujian Normalitas dapat dilakukan dengan mempergunakan uji Normal P-Plot. Berikut hasil dari uji Normal P-P Plot.

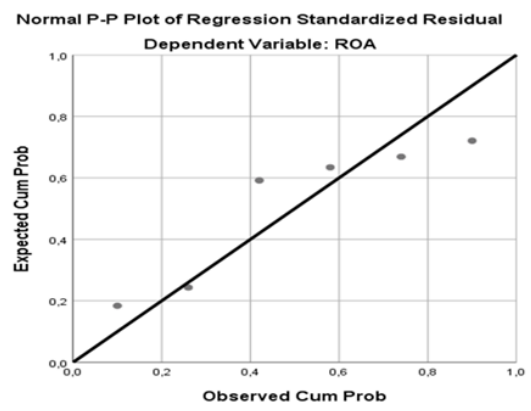

Gambar 1

Hasil Pengujian Normalitas Data

Dari hasil pengujian dapat terlihat bahwa data ada menyebar pada sekitaran garis miring dengan menyusuri garis miring yang ada, maka menurut model regresi dapat dinyatakan mencapai asumsi pengujian normalitas.

\section{Uji Multikolinearitas}

Dalam melakukan uji multikolinearitas untuk menentukan nilai VIF (Variance Inflation Factor ), maka total nilai cut off ditentukan nilai tolerance jika lebih besar dari pada 0,10 dapat diberikan sebuah penyataan bahwa data tidak terjadi multikol diantara variabel bebas, demikian juga apabila dari nilai VIF lebih kecil 10 (VIF < 10), maka dalam penelitian dinyatakan korelasinya tidak ada diakibatkan terlalu tinggi diantara variabel bebas.

Tabel 5

Hasil Uji Multikoleniaritas

\section{Coefficients}

a

\begin{tabular}{|c|c|c|}
\hline \multirow[t]{2}{*}{ Model } & \multicolumn{2}{|c|}{$\begin{array}{l}\text { Collinearity } \\
\text { Statistics }\end{array}$} \\
\hline & $\begin{array}{l}\text { Toleran } \\
\text { ce }\end{array}$ & VIF \\
\hline
\end{tabular}

1 \begin{tabular}{lll}
\hline CAR & 0,845 & 1,183 \\
\hline LDR & 0,868 & 1,153 \\
\hline BOPO & 0,972 & 1,029 \\
\hline
\end{tabular}

Didasari hasil pengujian yang dapat dilihat, maka dapat dijelaskaan bahwa pada setiap nilai tolerance variabel bebas yang memiliki nilai diatas 0,1 sedangkan nilai dari VIF dibawah 10. Maka hasil dari pengujian menunjukan model regresi pada pengujian ini tidak terjadi masalah multikolinearitas.

\section{Pengujian Heteroskedastisitas}

Bentuk pengujian regresi yang diakui yaitu dimana pada asil pengujian menunjukan tidak adanya heteroskedastisitas, atau bisa disebut juga hasilnya homokedastisitas. Hasil pengujian heteroskedastisitas mempergunakan model grafik Scatterplot.

\section{Gambar 2}

\section{Grafik Scatterplot Hasil Pengujian Heteroskedastisitas}

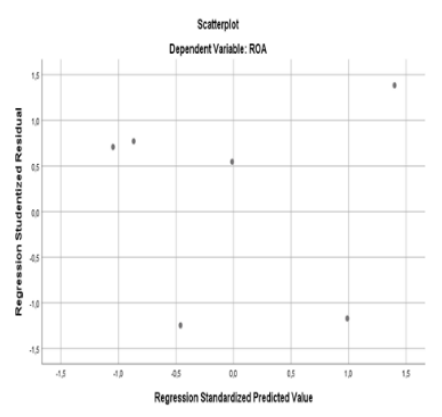

Hasil dari pengujian di atas, menunjukan data yang menyebar pada sekitaran garis serta arahnya sama dengan garis diagonal tersebut, maka pada bentuk pengujian regresi ini tidak terjadi heteroskedastisitas

\section{Pengujian Auto Korelasi}

Pengujian autokorelasi ini yaitu dengan menggunakan uji Run Test.

Hasil dari pengujian data auto korelasi, diketahui sebagai berikut: 
JRNAL ПMПAH

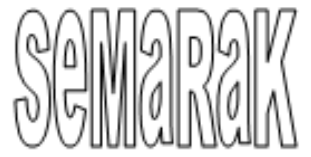

P-ISSN 2615-6849, E-ISSN 2622-3686

Jurnal Semarak,Vol.4,No.3,Oktober 2021, Hal (70-77)

@Prodi Manajemen Fakultas Ekonomi Universitas Pamulang
Tabel 6

Hasil Pengujian Auto Korelasi

\begin{tabular}{|l|r|}
\hline \multicolumn{1}{|c|}{ Runs Test } \\
\hline & \multicolumn{1}{c|}{ Uns tandardized Residual } \\
\hline Test Value ${ }^{\text {a }}$ & 0,01927 \\
\hline Cases $<$ Test Vahue & 3 \\
\hline Cases $>=$ Test Value & 3 \\
\hline Total Cases & 6 \\
\hline Number of Rums & 5 \\
\hline$Z$ & 0,456 \\
\hline Asymp. Sig. (2-tailed) & 0,648 \\
\hline a. Median & \\
\hline
\end{tabular}

Berdasarkan tabel 2 diatas diketahui nilai Asymp. Sig. (2-tailed) sebesar 0,648 > 0,05. Maka dapat disimpulkan bahwa tidak terdapat gejala atau masalah autokolerasi. sehingga analisis regresi linier dapat dilanjutkan

\section{Uji Regresi Linier Berganda}

Analisa regresi berganda dipergunakan untuk dapat mengambarkan keadaan yang terjadi pada variabel terikat (kriterium), ketika dua atau lebih variabel independen diasumsikan dimodifikasi (meningkatkan nilai) (Sugiyono, 2017:275).

Tabel 7 Hasil Uji Statistik

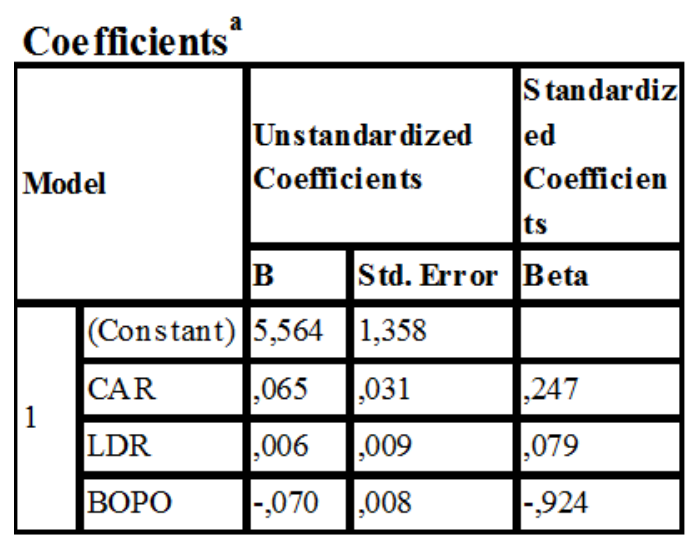

a. Dependent Variable:ROA

Berdasarkan penjelasan, maka diperoleh suatu hasil regresi sebagai berikut:

$\mathrm{Y}=5,564+0,065 \mathrm{X} 1+0,006 \mathrm{X} 2-0,070 \mathrm{X} 3$
Persamaan regresi yang dihasilkan diantaranya:

a. Dari persamaan regresi berganda di atas diketahui memiliki nilai konstanta 5,564 . Dengan demikian, tanpa adanya Capital Adequacy Ratio (CAR), Loan Ratio (LDR) dan Operating Profit (BOPO), maka Return on Total Assets (ROA) akan menjadi 5,564.

b. Berdasarkan Variabel rasio kecukupan modal memiliki koefisien bertanda positif sebesar 0,065. Hal ini menunjukan bahwa jika kecukupan modal mengalami kenaikan satu persen $(1 \%)$ maka nilai ROA akan naik sebesar $0,065 \%$.

c. Berdasarkan variabel Variabel keadaan kredit memiliki koefisien bertanda positif sebsar 0,006. Hal ini menunjukan bahwa jika keadaan kredit mengalami kenaikan satu persen $(1 \%)$ maka nilai ROA akan naik sebesar $0,006 \%$.

d. Berdasarka variabel Variabel biaya operasi terhadappendapatan operasi memiliki koefisien bertanda negatif sebesar -0,070. Hal ini menunjukan bahwa jika BOPO mengalami kenaikan satu persen (1\%) maka nilai ROA akan menurun sebesar $0,070 \%$.

\section{Pengujan Hipotesis}

a) Variabel Capital Adequacy Ratio (CAR) pengaruhnya terhadap Return On Assets

(ROA).

Berdasarkan dari hasil uji secara parsial variabel Capital Adequacy Ratio (CAR) terhadap Return On Assets (ROA) adalah tingkat signifikan sebesar $0,70 \geq 0,05$. Nilai signifkan ini menunjukan bahwa Capital Adequacy Ratio (CAR) tidak berpengaruh terhadap Profitabilitas (ROA). Hal ini menggambarkan bahwa ROA pada Bank OCBC NISP Tbk. tidak 
JRNAL ПMПAH

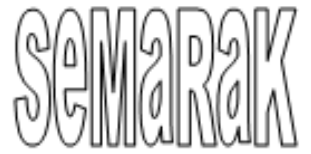

dipengaruhi oleh CAR, tetapi ada beberapa variabel lain yang bisa saja mempengaurhi ROA diluar variabel yang diteliti.

Hasil ini sejalan dengan penelitian yang dilakukan Natalia dkk (2018), Erna dan Joko (2017) yang menunjukan bahwa rasio kecukupan modal atau Capital Adequacy Ratio (CAR) tidak memiliki pengaruh terhadap Return On Assets (ROA), hal ini disebabkan modal yang tersedia tidakdimanfaatkan bank dengan optimal. Adapun alasannya karena peraturan Bank Indonesia yang mensyaratkan CAR minimal sebesar 8\% sehingga dengan hal tersebut bank berusaha untuk menjaga niai CAR tetap stabil.

\section{b) Variabel Loan to Deposits Ratio} (LDR) pengaruhnya terhadap Return On Assets

(ROA).

Berdasarkan dari hasil uji parsial variabel Loan to Deposits ratio (LDR) terhadap Return On Assets (ROA) adalah tingkat signifikan sebesar $0,566 \geq 0,05$. Nilai signifkan ini menunjukan bahwa Loan to Deposits ratio (LDR) tidak berpengaruh terhadap Profitabilitas (ROA).

Hasil penelitian menunjukkan bahwa loan to deposit ratio (LDR) tidak berpengaruh terhadap return on assets (ROA), menurut penelitian Kadek et al (2014). Namun hasil penelitian ini berlawanan dengan penelitian I Gusti dan Nyoman (2018) bahwa loan to deposit ratio (LDR) berpengaruh terhadap return on assets (ROA).

c. Dampak biaya operasional terhadap laba operasi (BOPO), pengembalian aset (ROA)
Hasil uji parsial pengaruh beban usaha terhadap laba usaha (BOPO) terhadap return on assets (ROA) pada tingkat materialitas 0,01

0,05 . Nilai kritis ini menunjukkan bahwa biaya operasional terhadap laba operasi (BOPO) mempengaruhi profitabilitas (ROA). Penelitian ini sejalan dengan penelitian Usman (2016) dan Ningsukma (2018) yang menyatakan BOPO berpengaruh signifikan terhadap ROA. Namun hasil penelitian ini bertolak belakang dengan penelitian yang dilakukan oleh Siti (2018) yang menyatakan BOPO tidak berpengaruh terhadap ROA. Koefisien pada variabel BOPO bertanda negatif yang menandakan bahwa setiap kenaikan nilai BOPO akan menurunkan nilai ROA, kondisi ini terjadi karena disetiap peningkatan biaya operasional bank yang tidak dibebarengi dengan peningkatan pendapatan operasional bank akan mengurangi laba sebelum pajak, sehingga akan menurunkan ROA. Akan tetapi jika bank mampu menjaga tingkat efisiensi dalam kegiatan operasionalnya dan meningkatkan pendapatan operasional, maka ROA akan meningkat (Kadek dkk,2014).

c) Variabel Capital Adequacy Ratio (CAR), Loan to Deposits Ratio (LDR) dan Biaya Operasional Pendapatan Operasional (BOPO) terhadap Return On Assets (ROA)

Hasil uji Simultan diperoleh dari nilai koefisien R Squre sebesar 0,977 atau $97,7 \%$ sedangkan sisanya 0,023 atau $2,3 \%$ merupakan fator lain dengan tingkat signifikan sebesar $0,035 \leq 0,05$. Hal tersebut menunjukan bahwa variabel independen berpengaruh secara simultan atau bersama-sama terhadap variabel dependen. 
JRNAL ПMПAH Sammandald

Berpengaruhnya ketiga variabel ini, membuat penting bagi Bank OCBC NISP Tbk. untuk mempertahankannya, karena untuk mendapatkan penambahan laba, maka dengan meningkatkan rasio kecukupan modal dan meningkatkan aset yang likuid serta meningkatkan efisiensi biaya operasional dengan BOPO akan meningkatkan profit yang didapatkan oleh Bank OCBC NISP Tbk.

\section{KESIMPULAN DAN SARAN Kesimpulan}

a) Hasil uji parsial yang diperoleh dari Pengaruh rasio kecukupan modal terhadap kemampuan bank menghasilkan laba adalah tingkat signifikan $0,70 \geq 0,05$, ini menunjukan bahwa rasio kecukupan modal tidak berpengaruh terhadap kemampuan bank menghasilkan laba. Hal ini mengindikasikan bahwa profitabilitas pada Bank OCBC NISP Tbk. tidak dipengaruhi oleh CAR.

b) Hasil uji parsial yang diperoleh dari Pengaruh, Loan to Deposits ratio (LDR) terhadap Return On Assets (ROA) adalah tingkat signifikan sebesar $0,566 \geq 0,05$. Nilai signifkan ini menunjukan bahwa Loan to Deposits ratio (LDR) tidak berpengaruh terhadap Profitabilitas (ROA).

c) Hasil uji parsial yang diperoleh dari Pengaruh Biaya Operasional Pendapatan Operasional (BOPO) terhadap Return On Assets (ROA) adalah tingkat signifikan sebesar 0,014 $\leq 0,05$. Nilai signifkan ini menunjukan bahwa Biaya Operasional Pendapatan Operasional (BOPO) berpengaruh terhadap Profitabilitas (ROA).

d) Adapun tes uji secara bersama-sama (simultan) diperoleh pengaruh rasio kecukupan modal, rasio pinjaman (LDR) dan beban usaha dari pendapatan operasional (BOPO) terhadap return on assets (ROA) Faktor kuadrat $\mathrm{R} \quad 0,977$ atau $97,7 \%$ sisanya 0,023 atau 2,3\% merupakan faktor lain dengan tingkat signifikansi $0,0350 \leq$ 05. Dengan hasil tersebut dapat disimpulkan bahwa antara variabel dependen dan variabelindependen mempunyai pengaruh secara simultan.

\section{Saran}

Berdasarkan kesimpulan diatas, maka peneliti dapat memberikan beberapa saran sebagai berikut :

1. Bagi manajemen PT Bank OCBC NISP, Tbk akan meningkatkan kinerja keuangan melalui profitabilitas bank (ROA) dan akan lebih memperhatikan aspek permodalan, likuiditas dan solvabilitas, profitabilitas masa depan. Manajemen bank dapat meningkatkan modal, meminjamkan kepada usaha kecil dan menengah dan modal langsung untuk pembangunan ekonomi Indonesia, dan bank dapat mengurangi biaya operasional yang tidak perlu, seperti mengurangi produk dan layanan perbankan yang merugi.

2. Penelitian ini bisa menjadi referensi untuk penelitian selanjutnya, penelitian juga masih banyak keterbatasan sehingga diharapkan pada penelitian selanjutnya variabel bebas dapat ditambah, tidak hanya berpatokan dengan 2 atau 3 variabel bebas serta data yang diambil bisa ditambah sehingga penelitian tersebut lebih beragam dan menghasilkan suatu informasi atau pengetahuan yang baru.

\section{REFERENCE}

Astawinetu, E. D., Handini, S. (2020). Manajemen Keuangan Teori dan Praktik.Surabaya : Scopindo Media Pustaka.

Diana, S. R. (2018). Analisis Laporan Keuangan dan Aplikasinya. Bogor : IN Media 
JRNAL ПMПAH

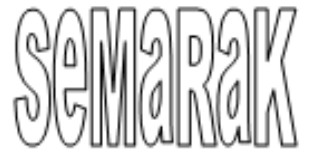

P-ISSN 2615-6849, E-ISSN 2622-3686

Jurnal Semarak,Vol.4,No.3,Oktober 2021, Hal (70-)

@Prodi Manajemen Fakultas Ekonomi Universitas Pamulang
Ghozali, I. (2018). Aplikasi Analisis Multivariate Dengan Program IBM SPSS 25. Semarang : Universitas Diponegoro.

Hartini, T. (2016). Pengaruh Biaya Operasional dan Pendapatan Operasional (BOPO) Terhadap Profitabilitas Bank Syariah Indonesia. I-Finance, 2(1), 20-34.

Hidayat, W. W. (2018). Dasar-Dasar Analisis Laporan Keuangan. Ponorogo: Uwais Inspirasi Indonesia .

Indartono, S. (2017). Pengantar Manajemen Character Inside. Yogyakarta : Universitas Negeri Yogyakarta.

Kasmir (2018). Pemasaran Bank. Jakarta : Kencana.

Nani, N., \& Sidik, S. (2021). Pengaruh Return On Asset (ROA) Dan Earning Per Share (EPS) Terhadap Harga Saham Pada PT. Asuransi Ramayana, TBK Periode 20102019. Jurnal Ilmiah PERKUSI, 1(3), 430-437.

POJK Nomor 51/POJK.03/2017. Tentang Penerapan Keuangan Berkelanjutan Bagi Lembaga Jasa Keuangan, Emiten, Dan Perusahaan Publik.

Sugiyono (2018). Metode penelitian Kuantitatif dan R\&B. Bandung : Alfabeta.

Sulastri, L. (2012). Manajemen Sebuah Pengantar ,Sejarah, Tokoh, Teori Dan Praktik. Bandung : La Goods Publishing.

Sutiman, Sutiman, Pengaruh Capital Adequacy Ratio, Ukuran Bank Dan Resiko Pembiayaan Terhadap Return On Asset Pada Bank Umum Syariah Di Indonesia Periode 20152019, Jurnal Ilmiah Semarak,4(2),67-80.

Tuti Indraswari,(2021), Pengaruh Perputaran Kas, Perputaran Piutang dan Perputaran Persediaan Terhadap Laba Bersih Serta Dampaknya Pada Nilai Perusahaan, 4 (2), 1-7.
Wartono, T., Tumanggor, M., Oktrima, B., \& Delimah, V. L. (2021, January). Analysis of Ratio and Financial Performance of Open Company Pharmaceutical Industry Which has Been Listing in Indonesia Stock Exchange (Case Study in Pharmaceutical Company PT. Kimia Farma. Tbk). In INCEESS 2020: Proceedings of the 1st International Conference on Economics Engineering and Social Science, InCEESS 2020, 17-18 July, Bekasi, Indonesia (p. 268). European Alliance for Innovation.

Wijaya, D. (2017). Manajemen Keuangan Konsep dan Penerapannya. Jakarta : PT Grasindo. 